\title{
MEWUJUDKAN KEUNGGULAN MADRASAH
}

\section{Mulyono}

\author{
Staf Pengajar pada PAI Fakultas Tarbiyah UIN Malang
}

\begin{abstract}
Existence of madrasah in Indonesia since decade 1990-an really show existence which continue strength, either through quantitative and also qualitative is. Relevant of growth, there [is] two fundamental matter needing careful with is. First, amount of private sector madrasah much more big than country madrasah; Both, madrasah born, grow, and expand from and for society. Level of society participation in education of this madrasah express that madrasah is true base on strength at society (education based community). All the growth push Departmental functionary of Religion, functionary of Local government, all Islamic educationist and also moslem society progressively believe that excellence of education of madrasah can be improved. They also believe that preeminent education which on the market by madrasah will be able to be accepted by moslem parent from various social status and circle. To reach excellence of madrasah hence enableness effort and renewal of system education of madrasah require to be [done/conducted] continuous so that can face various challenge according to growth of epoch in globalization era and area autonomy. Challenge faced by education system cover problems of generalization, quality of, education efficiency and relevansi.
\end{abstract}

Keyword: Excellence, Madrasah

\section{A. Pendahuluan}

Keberadaan madrasah di Indonesia sejak dekade 1990-an betulbetul menunjukkan eksistensi yang terus menguat, baik secara kuantitatif maupun kualitatif. Secara kuantitatif, data Departemen Agama RI tahun 2000-2001 menyebutkan bahwa saat ini terdapat 36.105 madrasah yang tersebar di seluruh wilayah Indonesia (Mastuki, 2001:35). Sedang secara kualitatif bersamaan dengan munculnya madrasah-madrasah baru dengan berbagai model di berbagai pelosok tanah air, maka juga mendorong lahirnya madrasah-madrasah yang dipercaya masyarakat sebagai madrasah favorit atau madrasah unggulan, karena memang secara fakta madrasah-madrasah favorit tersebut memiliki sejumlah keunggulan pendidikannya. Salah satu madrasah unggulan adalah Madrasah Ibtidaiyah Negeri (MIN) I Malang, Jawa Timur (Azra, 1999:78). Contoh madrasah elit lain adalah Madrasah Pembangunan UIN/dh. IAIN Syarif Hidayatullah Jakarta. Madrasah ini, yang mulanya merupakan sekolah laboratorium bagi Fakultas Tarbiyah UIN Jakarta, dalam beberapa tahun 
terakhir telah menjadi madrasah favorit di kalangan orang tua di Jakarta Selatan. (Azra, 1999:78).

Kisah sukses madrasah-madrasah elit ini mendorong Departemen Agama untuk mengembangkan madrasah-madrasah model di berbagai kota. Saat ini ada 57 Madrasah Tsanawiyah Model dan 35 Madrasah Aliyah Model yang dikembangkan di semua propinsi di Indonesia. Untuk merealisasikan program tersebut, Departemen Agama merencanakan madrasah negeri yang berada di lokasi-lokasi strategis akan dilengkapi dengan fasilitas, perlengkapan dan bahan pengajaran yang telah ditingkatkan, serta manajemen dan staf pengajar yang lebih terlatih. Madrasah model itu berperan sebagai madrasah model, untuk menjadi percontohan bagi standar pengembangan seluruh madrasah lainnya, baik negeri maupun swasta. Selain itu, madrasah-madrasah model diharapkan menjadi pusat sumberdaya pendidikan bagi madrasah-madrasah sekitarnya. Mereka juga diharapkan dapat memperlihatkan filosofi, konsep, prinsip, sistem dan prosedur-prosedur bagi pengajaran yang efektif dan pola belajar siswa aktif guna menjamin tercapainya prestasi yang lebih baik. (Azra, 1999:79). Di antara madrasah model yang diprogramkan Departemen Agama tersebut yang kini telah berkembang khususnya di Jawa Timur selain Madrasah Terpadu Jalan Bandung Kota Malang, yaitu MTsN Model Srono Banyuwangi dan MTsN I Jarakan Trenggalek.

Semua perkembangan tersebut mendorong pejabat Departemen Agama, pejabat Pemda, para ahli pendidikan Islam maupun masyarakat muslim semakin percaya bahwa kualitas pendidikan madrasah dapat ditingkatkan, tak jauh berbeda dengan sekolah. Mereka juga percaya bahwa pendidikan berkualitas yang ditawarkan oleh madrasah akan dapat diterima oleh orangtua muslim dari berbagai kalangan dan status sosial. Dalam artikel ini penulis membahas secara mendalam tentang bagaimana manajemen strategis dalam mewujudkan keunggulan madrasah?

\section{B. Membangun Mutu/Keunggulan Madrasah}

"Laa yahya walaa yamuutu : Hidup enggan mati segan", ungkapan yang dipetik dari potongan ayat Al-Qur'an tersebut yang seringkali dilontarkan oleh para pemerhati, penulis, peneliti, pakar maupun pejabat untuk menilai (laqob/menamai) lembaga pendidikan Islam di Indonesia khususnya madrasah yang memang sebagian besar kondisinya secara riil sangat memprihatinkan. Ungkapan itu menjadi tidak benar juga tidak tepat apabila keberadaan lembaga pendidikan Islam khususnya madrasah dilihat dari sudut teori evolusi Darwin. Hal ini dapat dianalogikan melalui suatu pertanyaan: "Unggul mana antara binatang dinosaurus dan bekicot?" Sebagian besar orang mengatakan bahwa unggul dinosaurus karena menurut cerita dan bukti fosil yang ada dinosaurus merupakan binatang raksasa yang panjang dan tingginya mencapai puluhan meter, 
sedang bekicot hanya binatang kecil yang jalannya sangat lambat. Tetapi dalam teori evolusi ternyata bekicot lebih unggul karena mampu berdaya tahan dalam segala iklim dan keadaan zaman, sedang dinosaurus walaupun bertubuh raksasa ternyata punah ditelan zaman karena tidak mampu berdaya tahan maupun beradaptasi/evolusi.

Dalam kacamata teori Darwin, madrasah memiliki beberapa keunggulan dibanding dengan jenis sekolah lainnya. Keunggulan paling unggul yang dimiliki madrasah antara lain: daya hidup (survival), daya juang, daya tahan (elant vital), daya adaptasi maupun evolusi, dan daya keanekaragaman (varitas). Daya hidup, daya juang dan daya tahan madrasah dapat dibuktikan bahwa madrasah mampu hidup di segala zaman dan keadaan, sejak zaman penjajahan Belanda, Jepang, kemerdekaaan, revolusi politik orba, orde baru, reformasi hingga abad 21 yang semakin menunjukkan eksistensinya. Hal ini dapat dibandingkan dengan sistem persekolahan lainnya, Taman Siswa yang pernah populer sebagai sekolah swasta pada zaman Belanda, Jepang, awal kemerdekaan, dan awal Orde Baru, ternyata sebagian besar mengalami kepunahan -kalah bersaing dengan sekolah negeri pada saat pemerintahan Orde Baru gencar membangun sekolah negeri khususnya SLTP di seluruh pelosok tanah air pada era 1980-an. Sistem persekolahan PGRI yang pernah populer sebagai sekolah swasta di era 1985-an mengiringi hadirnya SMP/SMA negeri ternyata sebagian besar mengalami gulung tikar saat harus bersaing dengan madrasah pada era 1990-an.

Sedang daya adaptasi dan evolusi dapat dibuktikan bahwa ketika zaman penjajahan, madrasah merupakan lembaga pendidikan yang berada di luar lingkaran sistem persekolahan penjajah Belanda dan Jepang. Setelah kemerdekaan para tokoh muslim berjuang sedikit demi sedikit memasukkan madrasah pada sistem pendidikan nasional, sehingga puncaknya lahir SKB Tiga Menteri 1975, UU No. 2 Tahun 1989 tentang Sistem Pendidikan Nasional, GBHN Tahun 1993 yang pertama kali memuat istilah madrasah yaitu SD/MI, UU No. 20 Tahun 2003 tentang Sisdiknas maupun berbagai peraturan yang menunjangnya. Sekarang madrasah sudah merupakan bagian inti dari sistem pendidikan nasional. Namun demikian madrasah walaupun sudah menjadi sekolah yeng berciri khas agama Islam, tidak pernah hilang jati dirinya sebagai lembaga pendidikan yang mengajarkan agama Islam. Dengan demikian sebenarnya madrasah mampu beradaptasi dan berevolusi sesuai dengan keadaan di sekitarnya namun tetap mempertahankan jati diri sebagai bagian penting lembaga pendidikan Islam.

Dari penjelasan di atas nyatalah bahwa madrasah sebenarnya memiliki berbagai potensi keunggulan, namun potensi keunggulan madrasah tersebut sebagian besar masih berupa potensi terpendam (latent) belum menjadi potensi yang aktif. Untuk mengaktifkan daya-daya 
keunggulan madrasah memang perlu daya dukung dan energi yang luar biasa dari berbagai pihak. Di sinilah nampaknya semua pihak harus berupaya keras bagaimana daya hidup madrasah tersebut dapat dihidupkan menjadi semakin hidup (meminjam istilah iklan TV) sehingga mencapai derajat keunggulan.

Keunggulan madrasah dipandang sebagai alternatif untuk meningkatkan kualitas pendidikan sekaligus kualitas SDM, yaitu kualitas kelembagaan madrasah dan kualitas lulusan. Madrasah bermutu/unggul diharapkan melahirkan manusia-manusia yang unggul yang berguna untuk membangun negara, bangsa, agama dan masyarakat dengan potensi intelektual tinggi, skill dan kemampuan teknologi yang kokoh serta didukung oleh integritas moral yang kuat. Tak dapat dipungkiri setiap orang menginginkan anaknya menjadi manusia unggul, hal ini terlihat dari animo masyarakat untuk mendaftarkan anaknya ke sekolah dan madrasah unggulan.

Madrasah unggulan adalah madrasah yang memiliki kualitas yang baik, baik input maupun outputnya. Terhadap kualitas madrasah dalam pengelolaan, manajemen, fasilitas dan lulusan yang berkualitas tinggi dalam pendidikan. Madrasah unggul atau dengan istilah lain madrasah model diharapkan menjadi contoh bagi sekolah-sekolah yang dianggap kurang maju dengan mengambil referensi pada madrasah unggul/model, misalnya dengan cara transfer guru dari madrasah unggul kepada madrasah yang kurang maju agar mencapai tujuan untuk menjadi madrasah unggul atau sebaliknya transfer guru dari madrasah yang tidak unggul kepada madrasah yang unggul untuk melihat cara-cara yang efektif untuk membangun madrasah unggul.

Kata "unggul" menyiratkan adanya superioritas dibanding dengan lain. Kata ini menunjukkan kata yang "kesombongan intelektual" yang sengaja ditanamkan di lingkungan lembaga pendidikan. Di negara maju untuk menunjukkan lembaga pendidikan yang baik tidak menggunakan kata unggul (excellent) melainkan efectif, develop dan essential (Nurcholis, 2002). Sedang Departemen Agama menggunakan istilah "madrasah model" bagi madrasah yang memang tergolong unggul atau memiliki karakteristik keunggulan tertentu dalam pengelolaan pendidikannya.

Dari sisi ukuran muatan keunggulan, madrasah/sekolah unggulan di Indonesia sebagian besar belum memenuhi persyaratan, sebagaimana yang diungkap Nurkholis (2002): "Sekolah Unggul yang Tidak Unggul”. Predikat lembaga pendidikan unggulan di Indonesia sementara ini hanya diukur dari sebagian kemampuan akademis, misalnya hasil UN (Ujian Nasional) berupa NEM/DANEM. Dalam konsep yang sesungguhnya lembaga pendidikan unggul adalah lembaga pendidikan yang secara terusmenerus meningkatkan kinerjanya dan menggunakan sumber daya yang dimilikinya secara optimal untuk menumbuh-kembangkan prestasi siswa 
secara menyeluruh. Berarti bukan hanya prestasi akademis saja yang tumbuh kembang, melainkan potensi psikis, fisik, etika, moral, religi, emosi, spirit, adversity dan intelegensi (Nurcholis, 2002).

Menurut Nurkholis (2002), ada beberapa kelemahan lembaga pendidikan yang sementara ini mendapat predikat sekolah unggul, yaitu: pertama, tidak adanya legitimasi dari pemerintah bukan atas inisiatif masyarakat atau pengakuan masyarakat. Kedua, sekolah unggulan hanya melayani golongan kaya, sementara orang miskin tidak mampu memasuki sekolah unggulan. Ketiga, profil sekolah unggulan hanya dilihat dari karakteristik prestasi yang tinggi berupa hasil ujian siswa, sarana prasarana yang lengkap, dana sekolah yang besar dan kegiatan belajar mengajar yang efektif, padahal sebutan sekolah unggul tidak bisa dilihat hanya dengan memandang itu saja karena masih banyak yang harus dilihat dari sisi lain (Nurcholis, 2002).

Menurut para pemerhati maupun pakar pendidikan, dalam perkembangannya lembaga pendidikan unggulan dapat dibedakan menjadi beberapa tipe, yaitu; Pertama, lembaga pendidikan unggulan yang mampu menghasilkan lulusan dengan prestasi akademik yang tinggi, namun harus dibarengi dengan in-put yang memang sudah unggul. Kedua, tipe lembaga pendidikan unggulan dalam hal fasilitas belajar. Tipe lembaga pendidikan ini memang memiliki fasilitas yang unggul, misalnya dilengkapi tempat-tempat praktek atau laboratorium yang memadai, gedung-gedung sekolah yang sesuai dengan kapasistas peserta didik, lapangan olahraga yang serba lengkap dan fasilitas-fasilitas lainnya. Lembaga pendidikan tipe ini sering disebut juga dengan lembaga pendidikan yang eksklusif. Tentunya biaya pendidikan di lembaga unggulan tipe kedua ini sangat mahal. Ketiga, lembaga pendidikan unggulan yang menitikberatkan pada proses belajar mengajar dengan membangun iklim pembelajaran yang kondusif di lingkungan lembaga. Dengan demikian akan dilahirkan out-put dengan prestasi yang unggul walaupun berasal dari in-put yang tidak tergolong unggul. Unggulan tipe ini terjadi proses belajar mengajar yang efektif dan kondusif.

Model tipe lembaga pendidikan unggulan yang menekankan pada proses belajar mengajar serta dukungan lingkungan kondusif inilah yang perlu diciptakan untuk membangun keunggulan madrasah. Dengan demikian madrasah unggul adalah madrasah yang dikelola secara professional dan modern serta didukung tenaga pendidik yang memiliki integritas moral tinggi, kreatif, inovatif, penuh dedikasi, ulet, tekun dan sabar guna mencapai kualitas pendidikan yang unggul sehingga mampu menghasilkan lulusan yang berkualitas.

Dengan demikian mutu/keunggulan madrasah yang sebenarnya dibangun secara bersama-sama oleh seluruh warga madrasah, bukan hanya pemegang otoritas lembaga saja. Pada konsep ini, dalam upaya 
membangun keunggulan kelembagaan dan keunggulan lulusan madrasah maka perlu dirancang kurikulum yang baik yang diajarkan oleh guru-guru yang berkualitas tinggi. Keunggulan madrasah terletak pada bagaimana cara pengelola madrasah merancang bangun lembaga sebagai organisasi, maksudnya adalah bagaimana struktur organisasi madrasah itu disusun, bagaimana para pengurus difungsikan dan diperansertakan dalam seluruh aspek gerak bangun madrasah, bagaimana warga madrasah berpartisipasi, bagaimana setiap orang memiliki peran tanggungjawab yang sesuai, bagaimana terjadi pelimpahan dan pendelegasian wewenang yang disertai rasa tanggungjawab, bagaimana pengelola mampu menciptakan lingkungan belajar yang kondusif, bagaimana peran serta masyarakat dapat ditumbuhkan dan ditingkatkan serta terakhir bagaimana semua orang merasa memiliki (sense of belonging) terhadap keberadaan, perkembangan dan kemajuan madrasah. Kondisi inilah kalau dilihat dari sudut teori evolusi Darwin bahwa madrasah memiliki daya keunggulan untuk tetap survive dalam segala kondisi dan keadaan. Potensi-potensi keunggulan tersebut sebenarnya sebagian besar merupakan potensi terpendam yang sudah dimiliki madrasah sejak awal keberadaannya. Tinggal bagaimana semua pihak membangkitkan dan mengoptimalkan potensi terpendam madrasah maupun lembaga pendidikan Islam secara umum menjadi kekuatan-kekuatan riil dalam rangka membangun keunggulan madrasah.

\section{Kebijakan Mewujudkan Keunggulan Madrasah}

Dari data yang ada menunjukkan eksistensi madrasah semakin menguat dua dasawarsa terakhir, sebenarnya ada dua hal pokok yang perlu dicermati bersama. Pertama, jumlah madrasah swasta jauh lebih besar daripada madrasah negeri; secara nasional problem ini menjadi lebih serius karena sebagian besar madrasah (lebih dari 90 persen) berstatus swasta (termasuk di dalamnya madrasah yang berada di bawah pesantren). Kedua, madrasah lahir, tumbuh, dan berkembang dari dan untuk masyarakat. Masyarakatlah yang mendirikan, membina dan mengembangkan madrasah. Besarnya partisipasi masyarakat dalam pendidikan madrasah ini mencerminkan bahwa madrasah memang berbasis kuat pada masyarakat (community based education) (Mastuki, 2001:36-37).

Keterkaitan masyarakat terhadap madrasah ini lebih ditampakkan sebagai "ikatan emosional" ketimbang pilihan rasional. Ikatan ini muncul dikarenakan bertemunya beberapa motivasi. Pertama, motivasi keagamaan. Bahwa mendirikan madrasah merupakan bagian dari ibadah kepada Allah, dengan harapan para pendirinya mendapatkan pahala dari-Nya. Motivasi agama ini didukung pula oleh ajaran wakaf yang memberi dorongan bahwa tanah atau sarana yang telah diwakafkan akan terus mengalir amalnya walaupun yang bersangkutan meninggal dunia. Maka tidak heran jika hampir seluruh lahan/tanah madrasah adalah wakaf. 
Kedua, motivasi untuk melaksanakan da'wah Islam. Hal serupa juga menjadi motivasi utama orang tua menyekolahkan anaknya di madrasah. Motivasi pendirian madrasah ini sering tanpa disertai dengan persiapan yang matang, baik dari segi tenaga pengajar maupun dana atau sarananya. Di samping itu, sering juga pendirian madrasah tanpa disertai pertimbangan, apakah di daerah dekatnya sudah ada madrasah serupa atau belum, sehingga di beberapa tempat terlihat banyaknya madrasah yang letaknya berdekatan antara satu sama lainnya, dengan jumlah murid yang kecil pula.

Ketiga, hasrat kuat masyarakat untuk berperan-serta dalam pendidikan dengan mendirikan lembaga pendidikan yang dapat menampung anak-anak di sekitar tempat tinggalnya. Mereka menginginkan anak-anaknya mendapat pendidikan agama yang cukup untuk bekal di akhirat nanti, di samping pendidikan umum.

Keempat, lebih bersifat pertimbangan ekonomis. Masyarakat pendukung madrasah menyadari bahwa mereka tidak mampu mengirimkan anak-anaknya ke sekolah yang letaknya jauh atau sekolah dengan bayaran "mahal", selain juga karena faktor ekonomis di mana anak-anak harus membantu orang tuanya mencari nafkah. Dalam kasus ini madrasah (atau diniyah) memberi alternatif pendidikan sore atau malam hari. Oleh sebab itu, ketika pemerintah melalui program INPRES SD mendirikan sekolah hampir di seluruh daerah yang semula telah ada madrasah, langkah ini dilemma baru bagi orang tua dan mengakibatkan madrasah di beberapa daerah gulung tikar, atau sebaliknya, SD Inpresnya tutup (Mastuki, 2001:37-38). Sebagaimana yang banyak dijumpai di beberapa wilayah di Sumatera yang masyarakatnya berbasis Islam kuat.

Kuatnya ikatan emosional masyarakat ini menyebabkan madrasah menjadi lebih massif, populis, mencerminkan suatu gerakan akar rumput (grass root)- karena itu madrasah lebih banyak di pedesaan dan daerah pinggiran (sub urban)- dan lebih dimotivasi secara instrinsik bahwa mencari ilmu dalam Islam sebagai suatu kewajiban.

Keterkaitan emosional ini, di satu sisi merupakan potensi dan kekuatan madrasah, dalam arti rasa memiliki (sense of belonging) dan tanggung jawab (sense of responsibility) masyarakat terhadap madrasah sangat tinggi karena merekalah yang mendirikan, mengelola dan mengembangkan. Hal ini juga menjadi faktor penting untuk menjamin sustainability (kelangsungan hidup) madrasah sebagai lembaga pendidikan swasta yang populis dan mandiri. Akan tetapi, di pihak lain kondisi ini justru menjadi kendala. Pertama, dari aspek penyelenggara, banyak madrasah yang bernaung di bawah organisasi keagamaan seperti NU, Muhammadiyah, Persis, Tarbiyah Islamiyah, Hidayatullah, dan lain-lain. Ada juga yang merupakan milik keluarga, yayasan, dan menjadi bagian dari pesantren. Keragaman ini menimbulkan bukan saja perbedaan 
orientasi dan kepentingan, tetapi kendala pembinaan serta penilaian mutu penyelenggaraan secara berkala termasuk oleh pemerintah. Kedua, secara kuantitas madrasah terus tumbuh berkembang di hampir seluruh pelosok tanah air yang tidak dibarengi dengan peningkatan kualitas dalam pengelolaannya. Ketiga, hambatan psikologis. Karena merasa sebagai pemilik atau pendiri yang membina madrasah sejak awal, sebagian pengelola (tokoh agama, organisasi keagamaan, yayasan, pesantren) tidak mudah menerima perubahan yang datang dari luar, termasuk dari pemerintah. Apalagi selama dekade pemerintahan Orde Baru menerapkan politik penyeragaman (unifikasi) yang mengakibatkan jenis dan jenjang pendidikan diatur serba rigid, kaku, dengan kurikulum sangat sentralistik, "serba atas" dan serba sama dari Jakarta hingga Papua (Mastuki, 2001:3839).

Kondisi ini menyebabkan pembinaan madrasah, terutama madrasah swasta, jauh lebih berat dan rumit (sophisticated) ketimbang sekolah yang sebagian besar - terbalik dari madrasah - berstatus negeri. Sayangnya, selama ini perhatian pemerintah terhadap madrasah yang telah berperan "mencerdaskan kehidupan bangsa" dirasakan cenderung tidak adil dan deskriminatif. Sebagai contoh, subsidi pemerintah yang diperuntukkan bagi madrasah swasta lebih rendah dibandingkan untuk madrasah negeri, dan jauh lebih rendah lagi dibandingkan dengan sekolah umum negeri. Dari data yang ada, masyarakat menyumbang $67,7 \%$ dari total keuangan MA, sedangkan selebihnya, 32,3\% berasal dari pemerintah. Pada madrasah-madrasah negeri memang subsidi pemerintah cukup besar. Namun, kondisi ini berbanding terbalik pada madrasah-madrasah swasta. MTs swasta memperoleh sumbangan dari perorangan/BP3 sebesar 87,6\%, sedangkan pemerintah hanya mensubsidi $12,4 \%$. Sebaliknya, MTs negeri memperoleh subsidi 84,4\% dari pemerintah, sedangkan sisanya, 15,6\% berasal dari sumbangan masyarakat. Keadaan di MI swasta masih lebih baik karena hanya 56,8\% keuangannya berasal dari orang tua/BP3, sementara pemerintah menyumbang 43,2\%.(Mastuki, 2001:39-40).

Menguatnya eksistensi madrasah baik secara kuantitatif maupun kualitatif yang dibuktikan dengan hadirnya madrasah-madrasah unggulan dan model di berbagai daerah, bukan semata-mata menjadi obat mujarrab untuk menyelesaikan persoalan yang ada hubungan dengan pengembangan madrasah yang sebagian besar berstatus swasta tersebut. Meski dalam sistem pendidikan nasional madrasah disebut sebagai sekolah umum yang berciri khas Islam, sebagian besar madrasah hingga kini mereka masih mencari bentuk idealnya. Hal ini disebabkan oleh problem identifikasi madrasah yang dominan bermuara pada beberapa hal: Pertama, problem inter-play (tarik ulur) kebijakan madrasah dalam integrasi sistem pendidikan nasional, dan; kedua, rendahnya tingkat apresiasi dan partisipasi masyarakat dalam upaya pengembangan mutu madrasah. 
Padahal, kiprah, peran dan fungsi madrasah dalam ikhtiar mencerdaskan bangsa adalah suatu hal yang tak lagi membutuhkan semacam perdebatan. Pasalnya, madrasah telah lama matang dalam wacana pendidikan masyarakat di Indonesia. Dengan demikian, akumulasi pengalaman madrasah dalam proses pendidikan terukur dari "usia" madrasah yang telah tua. Dari sini, diakui atau tidak, madrasah adalah potensi aktif yang terus bergerak dibawah permukaan informasi tentangnya seperti yang tergambarkan di atas. Madrasah tetap terjaga dinamikanya karena memiliki keliatan (adversity) yang luar biasa dalam mempertahankan keberadaannya sendiri (Hady, 2001:v).

Dengan demikian diharapkan semua pihak perlu memikirkan madrasah, menggagas ide-ide pemberdayaan tentang madrasah dan meyakini bahwa ada yang dapat diperbuat untuk madrasah. Dengan demikian, tidak hanya secara de jure madrasah berada di dalam arus utama (mainstream) strategi pendidikan nasional, tetapi juga secara de facto. Dengan demikian masyarakat pun tak lagi asing dengan keberadaan madrasah dan lembaga pendidikan Islam secara umum (Hady, 2001:vi).

Diakui bahwa saat ini sebagaian besar madrasah swasta sedang menghadapi kompleksitas permasalahan yang tak mudah dipecahkan. Keadaan madrasah swasta secara individual, sangat variatif dan rata-rata memprihatinkan. Secara kolektif, madrasah tidak memiliki kebersamaan sehingga daya-suai dan daya rubahnya atas kehidupan masyarakat muslim kurang maksimal.

Salah satu terobosan yang perlu dijalankan adalah perubahan sistem madrasah dan pola-pola manajemen madrasah baik pada tingkat madrasah maupun tingkat koordinasi yang lebih tinggi. Pada tingkat madrasah, perubahan manajemen kelembagaan dimaksudkan untuk meningkatkan keunggulan madrasah secara individual, dan pada tingkat koordinasi yang lebih dimaksudkan untuk meningkatkan kualitas dan daya guna madrasah secara bersama-sama dan menyeluruh untuk mewujudkan visi dan misi yang diyakini dan diemban bersama (Hady, 2001:2).

Pada dasarnya, secara organisasional, madrasah merupakan organisasi yang mengelola diri (self-organized) untuk tumbuh dan berkembang sesuai dengan karakteristiknya. Dan pengelolaan diri ini dijalankan oleh para pimpinan madrasah melalui sebuah mekanisme manajemen operatif. Namun, karena madrasah di Indonesia merupakan sub-sistem dalam makro-sistem pendidikan nasional, dan tanggungjawab pengelolaannya dibebankan kepada Departemen Agama, maka pengelolaan-diri madrasah, secara individu, tidak cukup untuk memberikan dampak perubahan yang signifikan dan luas bagi peningkatan kualitas masyarakat muslim Indonesia. Selain itu, menyadari bahwa hampir semua madrasah di Indonesia tergolong miskin dalam 
berbagai sumber (resourceless) untuk dapat mengembangkan diri, dan menyadari pula bahwa madrasah saat ini tidak dikelola sebagaimana mestinya, maka diperlukan langkah-langkah strategis baik untuk meningkatkan keunggulan madrasah secara individual maupun keunggulan madrasah secara menyeluruh (Hady, 2001:2).

Dalam meningkatkan keunggulan madrasah, beberapa tahun terakhir, Departemen Agama telah melakukan kebijakan strategis, antara lain: pertama, pemerataan pendidikan, di mana pembangunan madrasah lebih menekankan pada terwujudnya pemerataan kesempatan memperoleh pendidikan bagi warga negara, terutama untuk anak-anak usia wajib belajar (7-15 tahun). Oleh karenanya, titik berat pembangunan diletakkan pada pembangunan madrasah tsanawiyah. Kedua, peningkatan mutu pendidikan madrasah, yaitu peningkatan kualitas manajerial dan operasional pembelajaran di madrasah. Pengembangan ini mencakup peningkatan kualitas semua komponen yang menunjang baik langsung maupun tidak langsung berpengaruh terhadap keberhasilan pembelajaran di madrasah. Ketiga, link and match, yaitu bahwa pendidikan di madrasah harus dipersepsi sebagai proses yang melibatkan banyak pihak, dan karenanya haruslah dapat memenuhi keinginan banyak pihak, seperti pihak siswa sendiri, orang tua siswa, masyarakat biasa, masyarakat industri serta masyarakat secara umum. Keempat, efektivitas dan efisiensi, yaitu tercapainya tujuan-tujuan yang diharapkan dengan cost yang seminimal mungkin (Hady, 2001:5-6).

Di samping itu kebijakan strategis mewujudkan pembangunan madrasah untuk mencapai keunggulan, Direktorat Jenderal Pembinaan Kelembagaan Agama Islam atau dalam hal ini Direktorat Pembinaan Perguruan Agama Islam menerapkan strategi pengembangan sebagai berikut: Pertama, pencerahan madrasah, yaitu menitikberatkan pada kualitas pendidikan, pelaksanaan pencerahan madrasah melahirkan beberapa terobosan berupa pembentukan madrasah-madrasah model, pencanangan madrasah terpadu, penyusunan kurikulum esensial berdasarkan pendekatan berbasis kompetensi, dan program bantuan yang menopang peningkatan kualitas madrasah, seperti pengadaan perpustakaan, laboratorium, pelatihan manajemen, pelatihan guru kelas dan guru mata pelajaran, dan lain-lain. Kedua, pemberdayaan madrasah (empowering madrasah), yaitu upaya pemberdayaan madrasah agar tetap bertahan hidup dan tetap menjadi bagian dari sistem pendidikan nasional. Di tingkat pendidikan dasar, strategi pemberdayaan ini menjadi bagian dari upaya nasional dalam menuntaskan Wajib Belajar Sembilan Tahun. Di sini, Departemen Agama juga memberikan bantuan-bantuan fisik, pelatihan, biaya operasional, dan juga beasiswa (Hady, 2001:6-7). Upayaupaya di atas agar madrasah tetap terjamin sebagai lembaga pendidikan Islam yang memiliki daya tahan (fiabilitas) dan daya hidup (élan vital) serta daya keunggulan di masa depan. 


\section{Kesimpulan}

Munculnya madrasah yang tergolong unggul seperti MIN Malang I (Madrasah Terpadu), MI Jenderal Sudirman Malang, MTsN Model Srono Banyuwangi, MTsN Jarakan Trenggalek, SMU/MA Insan Cendekia Serpong Tangerang, maupun madrasah unggulan/model yang tersebar di berbagai daerah layak untuk dijadikan contoh bagi pengembangan madrasah lainnya. Kajian madrasah model sebenarnya sudah banyak dibahas oleh para pakar khususnya di Jurnal Madrasah Depag maupun dalam forum-forum diskusi ilmiah lainnya, dan demikian juga dalam penelitian-penelitian. Namun demikian, hal utama yang perlu disadari oleh semua pihak adalah keunggulan yang dimiliki oleh suatu madrasah belum tentu dapat ditransfer serta merta oleh madrasah lain yang tidak tergolong unggul karena berbagai perbedaan sumber daya dan sumber dukung yang berbeda.

Penulis berasumsi bahwa bagaimana menciptakan mutu/keunggulan madrasah yang bersumber dari potensi-potensi yang dimiliki madrasah dengan tetap menumbuh-kembangkan daya kreativitas, varitas/keanekaragaman, inovatif, dan model pada masing-masing madrasah sesuai dengan kemampuan, daya dukung dan kebutuhan masyarakat sekitar. Mengingat era otonomi daerah seperti sekarang ini maupun penerapan manajemen berbasis sekolah (MBS) serta berlakunya KTSP (Kurikulum Tingkat Satuan Pendidikan) nampaknya memberikan ruang gerak yang lebih leluasa terhadap upaya-upaya munculnya kreativitas dan keanekaragaman keunggulan lembaga pendidikan termasuk madrasah. Namun agar pertumbuhan pada masing-masing madrasah ada tolak ukur yang baku yang dapat diketahui semua pihak maka perlunya pengoptimalan pelaksanaan akreditasi madrasah sesuai dengan kaidah-kaidah akreditasi yang benar.

Dengan demikian untuk mewujudkan keunggulan madrasah setidaknya ada tiga hal manajemen strategis yang perlu dilakukan: pertama, kebijakan strategis pemerintah/Depag yang mendukung terhadap perkembangan keunggulan madrasah diantaranya perlunya alokasi pendanaan yang mencukupi, bantuan sarana-prasana dan pelatihan/penyediaan SDM yang handal; kedua, pelaksanaan akreditasi yang benar dan tepat; serta ketiga, adanya usaha-usaha semaksimal mungkin seluruh warga madrasah untuk mengelola diri dan mengembangkan diri agar mencapai keunggulan.

\section{E. Daftar Pustaka}

Azra, Azyumardi, Pendidikan Islam Tradisi dan Modernisasi Menuju Milenium Baru, Jakarta: Logos Wacana Ilmu, 1999.

Hady, M. Syamsul Seri Informasi Pendidikan Islam, No. 8, Manajemen Madrasah, Jakarta: Departemen Agama RI, Direktorat Jenderal 
Kelembagaan Agama Islam, Bagian Proyek EMIS Perguruan Agama Islam Tingkat Dasar, 2001.

Irfan, Moh. Menyoal Sistem Akreditasi Madrasah, Jurnal Madrasah, Jakarta: Departemen Agama Pusat, Vol. 5, No. 1, 2001.

Mastuki, Seri Informasi Pendidikan Islam No. 6, Menelusuri Pertumbuhan Madrasah di Indonesia. Jakarta: Departemen Agama RI, Direktorat Jenderal Kelembagaan Agama Islam, Bagian Proyek EMIS Perguruan Agama Islam Tingkat Dasar, 2001.

Nurkholis, Sekolah Unggul yang Tidak Unggul. Artikel. Jakarta: www. Sekolah Unggul.com. 2002.

Peraturan Pemerintah Republik Indonesia Nomor 19 Tahun 2005 tentang Standar Nasional Pendidikan. Jakarta: CV. Tamita Utama, 2006.

Undang-Undang Republik Indonesia No. 20 Tahun 2003 tentang Sistem Pendidikan Nasional, Bandung: Citra Umbara. 